\title{
Fiscal Policy and Macroeconomic Stability: New Evidence and Policy Implications
}

\author{
Xavier Debrun y Radhika Kapoor
}

Revista de Economía y Estadística, Cuarta Época, Vol. 48, No. 2 (2010), pp. 69-101.

http://revistas.unc.edu.ar/index.php/REyE/article/view/4107

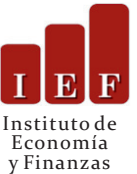

La Revista de Economía y Estadística, se edita desde el año 1939. Es una publicación semestral del Instituto de Economía y Finanzas (IEF), Facultad de Ciencias Económicas, Universidad Nacional de Córdoba, Av. Valparaíso s/n, Ciudad Universitaria. X5000HRV, Córdoba, Argentina.

Teléfono: 00 - 54 - 351 - 4437300 interno 253.

Contacto: rev eco estad@eco.unc.edu.ar

y Finanzas

Dirección web http://revistas.unc.edu.ar/index.php/REyE/index

Cómo citar este documento:

Debrun, X. y Kapoor R. (2010). Fiscal Policy and Macroeconomic Stability: New Evidence and Policy Implications. Revista de Economía y Estadística, Cuarta Época, Vol. 48, No. 2 (2010), pp. 69-101.

Disponible en: <http://revistas.unc.edu.ar/index.php/REyE/article/view/4107>

El Portal de Revistas de la Universidad Nacional de Córdoba es un espacio destinado a la difusión de las investigaciones realizadas por los miembros de la Universidad y a los contenidos académicos y culturales desarrollados en las revistas electrónicas de la Universidad Nacional de Córdoba. Considerando que la Ciencia es un recurso público, es que la Universidad ofrece a toda la comunidad, el acceso libre de su producción científica, académica y cultural.

http://revistas.unc.edu.ar/index.php/index

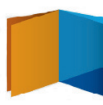




\title{
Fiscal Policy and Macroeconomic Stability: New Evidence and Policy Implications
}

\author{
Xavier Debrun ${ }^{*}$ \\ International Monetary Fund \\ xdebrun@imf.org \\ RADHICKA KAPOOR \\ London School of Economics
}

\begin{abstract}
The paper revisits the empirical link between fiscal policy and macroeconomic stability. Our basic presumption is that by definition, the operation of automatic stabilizers should always and everywhere contribute to greater macroeconomic stability (output and consumption). However, two stylized facts seem at odds with that prediction. First, the moderating effect of automatic stabilizers appears to have weakened in advanced economies between the mid-1990s and 2006 (the end of our main sample). Second, automatic stabilizers do not seem to be effective in developing economies. Our analysis addresses these apparent puzzles by accounting for the government's ambivalent role as a shock absorber and a shock inducer for determinants of macroeconomic volatility over time. Results provide strong support for the view that fiscal stabilization operates mainly through automatic stabilizers.
\end{abstract}

Keywords: Economic stabilization ; Fiscal policy ; Fiscal stability. JEL Classification: E62; H6.

\footnotetext{
* International Monetary Fund. Corresponding address: $70019^{\text {th }}$ Street, Washington, DC, 20431, USA.

The views expressed in this paper are those of the authors and do not necessarily represent those of the IMF or IMF policy. Without implication, we thank Antonio Afonso, Torben Andersen, Thomas Baunsgaard, Helge Berger, Olivier Blanchard, Carlo Cottarelli, Mark de Broeck, Luc Everaert, Antonio Fatàs, Davide Furceri, Steinar Holden, Albert Jaeger, Yngve Lindh, Mats Persson, and seminar participants at the IMF, the Banca d'Italia, and the Nordic Economic Policy Review conference for stimulating comments and suggestions.
} 


\section{RESUMEN}

Este documento retoma el estudio de la relación empirica entre la política fiscal y la estabilidad macroeconómica. Nuestro supuesto básico es que, por definición, el funcionamiento de los estabilizadores automáticas debería siempre y en todas partes contribuir a una mayor estabilidad macroeconómica (producción y consumo). Sin embargo, dos hechos estilizados parecen estar en desacuerdo con esa predicción. En primer lugar, el efecto moderador de los estabilizadores automáticos parece haberse debilitado en las economías avanzadas entre los años 1990 y 2006. En segundo lugar, los estabilizadores automáticos no parecen ser eficaces en las economías en desarrollo. Nuestro análisis aborda estos enigmas aparentes por medio del análisis del papel ambivalente del gobierno como un amortiguador e inductor de shocks sobre los determinantes de la volatilidad macroeconómica en el tiempo. Los resultados proporcionan un fuerte apoyo a la opinión de que la estabilización fiscal opera principalmente a través de los estabilizadores automáticos.

Palabras clave: Estabilización Económica; Política Fiscal; Estabilidad Fiscal. Clasificación JEL: E62; H6.

\section{INTRODUCTION}

Recent developments in macroeconomic modeling and pressing policy challenges have revived the classic debate on the effectiveness of fiscal policy as an instrument of macroeconomic stabilization (van der Ploeg, 2005). On the theory side, the rapid development of micro-founded general equilibrium models with non-Ricardian features has allowed researchers to assess the benefits of fiscal stabilization in a coherent and rigorous analytical framework (see Botman and others, 2006, for a survey). These studies confirm the conventional wisdom that a timely countercyclical response of fiscal policy to demand shocks is likely to deliver appreciably lower output and consumption volatility (Kumhof and Laxton, 2009). However, well-intended fiscal activism can also be undesirable, when shocks are predominantly affecting the supply side (Blanchard, 2000), or squarely destabilizing, when information, decision and implementation lags unduly lengthen the transmission chain. On the policy side, a growing number of countries turned to fiscal policy as their primary stabilization instrument either because of changes in their monetary regime (currency board, hard peg, participation in a monetary union) or because financial conditions deteriorated to the point of making monetary policy ineffective (Spilimbergo and others, 2008). 
Fiscal policy can contribute to macroeconomic stability through three main channels. The first is the automatic reduction in government saving during downturns and increase during upturns, cushioning shocks to national expenditure (Blinder and Solow, 1974). Such automatic stabilization occurs because tax revenues tend to be broadly proportional to national income and expenditure, whereas public spending reflects government commitments independent of the business cycle and entitlement programs specifically designed to support spending during downturns, including unemployment benefits. ${ }^{2}$ Also, to the extent that government consumption is less volatile than other components of GDP, the public sector contributes to output stability through a mere composition effect of domestic expenditure. Second, governments can deliberately change public spending and tax instruments to offset business cycle fluctuations. Finally, the structure of the tax and transfer system can be designed to maximize economic efficiency and market flexibility, thereby enhancing the resilience of the economy in the face of shocks. The notion of fiscal stabilization pertains to the first two channels.

The public's demand for government-induced stability reflects a number of factors that may vary over time and across countries, including the inherent resilience of the economy and the existence of alternative stabilizers, such as an effective monetary policy and unrestricted access of individual agents to financial instruments. During the recent crisis, the perceived need for fiscal stabilization has been unquestionably high: the resilience of national economies was impaired by the depth and the global nature of the shock, agents faced either limited access to or high cost of self-insurance through credit markets and financial institutions, and the firepower of monetary policy was constrained by the zero-bound on nominal interest rates. In the short term, the stabilizing role of fiscal policy relies on effective automatic stabilizers and on the capacity of governments to engineer (and credibly phase out) a fiscal stimulus in a timely fashion.

This paper puts the current revival of fiscal stabilization policies in a broader perspective by revisiting the contribution of fiscal policy to macroeconomic stability in both industrial and developing economies over the last 40 years. The study builds on earlier work by Galì (1994), van den Noord (2002), and Fatás and Mihov (2001, 2003), who investigate directly the cross-country relationship between fiscal policy indicators and output

2. Darby and Mélitz (2008) and Furceri (2009) show that social spending _ including health and retirement benefits - is more countercyclical than generally acknowledged. For instance, early retirement and sick leave — which often protects employees against involuntary separation — are more likely to be used during downturns. 
volatility. That approach has the advantage to incorporate in simple statistical tests various determinants of the stabilizing effect of fiscal policy, including policymakers" "reaction functions" and the actual impact of fiscal measures on output and private consumption. The resulting, reduced-from empirical relations thus provide useful information on the effectiveness of fiscal policy, while avoiding the methodological issues related to the estimation of fiscal "multipliers." Indeed, multipliers' estimates highly sensitive to the identification procedure of exogenous fiscal impulses (structural VARs, narratives, or DSGE model simulations), the nature of the shock (tax cuts, spending increases), and the behavior of monetary policy (Blanchard and Perotti, 2002; Perotti, 2005; Romer and Romer, 2008; and Horton, Kumar and Mauro, 2009 for a survey).

Existing analyses of fiscal stabilization tend to focus on the role of automatic stabilizers in industrial economies. Many of those draw on the seminal insights of Gali (1994) and revolve around the negative relationship between output volatility and government size, used as a proxy for the cyclical sensitivity of the budget balance. While the literature generally confirms the countercyclical impact of automatic stabilizers, the relationship appears to be a complex one. First, non-linearities seem to exist, ${ }^{3}$ suggesting that the adverse effect of high tax rates on an economy's resilience could more than offset the action of automatic stabilizers. Second, the relationship may be changing over time as structural changes moderating output volatility could be faster in economies with leaner governments. ${ }^{4}$ Finally, the relationship does not seem to hold beyond a narrow sample of industrial OECD countries. ${ }^{5}$ Debrun, PisaniFerry and Sapir (2008) addressed the first two concerns, introducing a timedimension in the Fatás-Mihov sample to control for potential determinants of the "great moderation," (i.e. the steady decline in output volatility observed between the mid-1980s and the recent past). Their results confirm the effectiveness of automatic stabilizers in reducing output volatility.

This paper looks further into the robustness of the results described above. Our contribution rests on 4 elements. First, our sample includes 49

3. Examples include Silgoner, Reitschuler and Crespo-Cuaresma (2002), and Martinez-Mongay and Sekkat (2005).

4. Debrun, Pisani-Ferry and Sapir (2008) and Mohanty and Zampolli (2009) document an apparent breakdown of the relationship between government size and output volatility in the 1990s.

5. Fatás and Mihov (2003) find that government size actually increases output volatility in a cross-section of 91 countries. Viren (2005), using an even larger cross-section of 208 countries and territories, concludes that "the relationship between government size and output volatility is either nonexistent or very weak at best". Mohanty and Zampolli (2009) find that even among OECD countries government size only has a modestly negative impact on output volatility. 
industrial and developing countries for which reasonably long time series exist for fiscal data covering the general government. Second, we take into account the potentially destabilizing impact of fiscal policy, as public finances are used to attain other goals than macroeconomic stability. Should bigger governments produce larger fiscal shocks, estimates of the impact of automatic stabilizers would be biased. Third, we account for the role of potential substitutes to fiscal policy as a macroeconomic insurance mechanism, including financial development, improved monetary policy credibility, and better economic policy governance. These variables may account for the decline in output volatility observed until the recent crisis and may prove important to properly identify the causal relation between automatic stabilizers and volatility (see Debrun, Pisani-Ferry, and Sapir, 2008, and Mohanty and Zampolli, 2009). Fourth, we investigate the extent to which fiscal policy contribute to lower private consumption volatility, as the latter is more closely related to welfare.

The main results can be summarized as follows. First, automatic stabilizers strongly contribute to output stability regardless of the type of economy (advanced or developing), confirming the effectiveness of timely, predictable and symmetric fiscal impulses in stabilizing output. The impact on private consumption volatility is quantitatively weaker and statistically less robust. Second, countries with more volatile cyclically-adjusted budget balances also exhibit more volatile output and private consumption. However, the result could be tainted by a reverse causality problem that we could not satisfactorily address with instrumental-variables techniques due to a weakinstrument problem. Third, access of individual consumers to credit appears to exert a stabilizing influence on output and private consumption. A weaker contribution of credit supply to smooth cyclical fluctuations could thus increase the public's appetite for fiscal stabilization.

The rest of the paper is structured as follows. Section 1 discusses data issues and reviews stylized facts. Section 2 develops the econometric analysis, while Section 3 discusses the results and draws policy implications.

\section{DAta And Stylized FACTS}

\section{II.1 Governments as shock absorbers and shock inducers}

The size of automatic stabilizers is commonly approximated by the ratio of general government expenditure to GDP. Using a rule of thumb according to which the elasticity of government revenues and expenditure 
(both in levels) to the output gap is 1 and 0 respectively, the expenditure-toGDP ratio is indeed equal to the semi-elasticity of the overall budget balance (in percent of GDP) to the output gap. ${ }^{6}$

However, if size matters for automatic stabilization, it could also prove harmful for macroeconomic stability if bigger governments tend produce larger fiscal shocks than their leaner counterparts. To avoid an omittedvariable bias, it is important to control for this possibility in the econometric analysis. The rest of this sub-section constructs a set of mutually-consistent fiscal indicators capturing three relevant dimensions of fiscal policy: automatic stabilizers, systematically stabilizing discretionary policy, and nonsystematic policy (which can be stabilizing or not).

\section{II.1.a Three dimensions of fiscal policy}

To look at the cyclical properties of the overall budget balance, it is common to split it in two components: the cyclical balance and the cyclically-adjusted balance (see for instance, Galì and Perotti, 2003). Changes in the cyclical balance give an estimate of the budgetary impact of aggregate fluctuations through the induced changes in tax bases and certain mandatory outlays. By construction, the cyclical balance is zero when the output gap is closed (actual output is on trend), and its variations are thought to be outside the immediate control of the fi scal authorities. Subtracting the cyclical balance from the overall balance yields the cyclically-adjusted balance $(C A B)$, or the hypothetical overall balance one would observe if output was on trend (or "potential") level. Changes in the $C A B$ are generally interpreted as resulting mostly ${ }^{7}$ from discretionary actions by policymakers.

The $C A B$ itself reflects two dimensions of fiscal policy relevant for our analysis. The first is the effect of policy decisions systematically related to changes in the actual or expected cyclical conditions of the economy. For instance, governments wishing to actively pursue a countercyclical policy could reduce taxes or increase government consumption whenever the economy is in a recession, while withdrawing the stimulus during the recovery and reducing public spending during booms. The response of the $C A B$ to the cycle can either be pro-cyclical (running against automatic stabilizers) or countercyclical (augmenting the effect of automatic stabilizers). The second source of variations in $C A B \mathrm{~s}$ arises from budgetary changes that are not

6. See equations (1) and (2) below.

7. Studies of the fiscal stance often exclude interest payments, as they reflect past policies (public debt) and financial conditions. 
the result of the average response of fiscal authorities to the business cycle. This "exogenous" $C A B$ can either reflect extraordinary fiscal stabilization efforts - such as those adopted in response to the recent crisis - or destabilizing fiscal impulses associated with other objectives of public finances (redistribution and effi ciency), or non-economic considerations (e.g. electoral budget cycle).

Thus, from now, fiscal policy will be discussed in light of those three dimensions of the overall balance, namely:

(i) automatic stabilizers;

(ii) the "cyclical fiscal policy," reflecting the systematic response of the $C A B$ to the business cycle;

(iii) and the "exogenous discretionary fiscal policy" capturing $C A B$ changes that are not systematically related to current macroeconomic conditions. ${ }^{8}$

\section{II.1.b. Quantifying the three dimensions}

Data analysis alone does not allow disentangling the impact of automatic stabilizers from that of systematic discretionary stabilization. To solve that identification problem, we simply assume that automatic stabilizers are adequately measured by the ratio of public expenditure to GDP. That assumption enhances the comparability of our results with related studies and provides a simple and transparent metric applicable to all countries. But it entails a potential measurement error that we will need to keep in mind when interpreting the results (see further discussion below).

A $C A B$ consistent with our assumption is needed to derive indicators of the "cyclical" and exogenous policies defined above. As indicated earlier, government size is an exact measure of the sensitivity of the budget balance to the business cycle if revenue and expenditure elasticities to output are 1 and 0 respectively. To see this, define the $C A B$ (in percentage of trend output $Y^{*}$ as:

$$
\begin{aligned}
C A B & \equiv \frac{R\left(Y^{*} / Y\right)^{\eta_{R}}}{Y} \frac{Y}{Y^{*}}-\frac{G\left(Y^{*} / Y\right)^{\eta_{G}}}{Y} \frac{Y}{Y^{*}} \\
& =r\left(Y^{*} / Y\right)^{\eta_{R}-1}-g\left(Y^{*} / Y\right)^{\eta_{G}-1},
\end{aligned}
$$

8. This is the terminology used by Fatás and Mihov (2009). For a more detailed discussion of cyclical adjustment, see Fedelino, Ivanova and Horton (2009). 
Where $r$ is total revenue as a ratio of GDP $(Y), Y^{*}$ is the trend level of output, $\eta_{R}$ is the elasticity of revenue to the output gap, $g$ is the expenditure to GDP ratio, and $\eta_{G}$ is the elasticity of expenditure to the output gap. Setting $\eta_{R}=1$ and $\eta_{G}=0$ and denoting by $b$ the overall budget balance (in percent of GDP) yields:

$$
\begin{aligned}
C A B & =r-g\left(Y^{*} / Y\right)^{-1} \\
& =b-g\left(Y^{*} / Y\right)^{-1}+g \\
& =b-g\left(Y / Y^{*}-1\right) \\
& =b-g y,
\end{aligned}
$$

Where $y$ is the output gap in percentage of trend output $y \equiv\left(Y-Y^{*}\right) / Y^{*}$, and $g y$ is the cyclical balance. This formally establishes that the public expenditure ratio is the semi-elasticity of the budget balance (in percent of GDP) to the output gap. ${ }^{9}$

Indicators of the cyclical and exogenous/discretionary fiscal policies can then be estimated for each country in our sample, using a simple timeseries regression: ${ }^{10}$

$$
C A B_{t}=\alpha+\beta y_{t}+\gamma C A B_{t-1}+\mu_{t},
$$

where the output gap $y_{t}$ is calculated as the relative deviation of actual GDP from an HP trend. The first-order autoregressive term on the right-hand side of (3) accounts for persistence in budget balances, and effectively eliminates the severe first-order serial correlation of residuals observed in static regressions.

The cyclical fiscal policy is captured by $\beta$ the short-term response of the $C A B$ to the output gap. A negative value implies that a cyclical upturn (downturn) tends to deteriorate (improve) the $C A B$, indicating that government actions are systematically destabilizing and offset — at least partly - the impact of automatic stabilizers on the economy. On the other hand, a positive coefficient on $y_{t}$ implies that on average, the government seeks to increase the counter-cyclical bent of fi scal policy through discretionary measures.

The effectiveness of fiscal policy entails reverse causality from $C A B$ to $y$, introducing a downward bias in OLS estimate of $\beta$. Also, equation (3)

9. Of course, this does not mean that automatic stabilizers arise from the expenditure side since we assumed $\eta_{G}=0$.

10. Galì and Perotti (2003), Wyplosz (2006) and Fatàs and Mihov (2009) use a similar specification to study the cyclical features of fiscal policy. Fatàs and Mihov (2003) and Afonso, Agnello and Furceri (2009) also rely on a regression-based method to distinguish between cyclicality, persistence, and the volatility of public expenditure. 
is parsimonious by necessity (time series are short in some countries), which could create an omitted variable bias. To alleviate potential biases in the estimated $\beta$ 's, instrumental variable (IV) techniques are used. Instruments for the output gap include its own lagged value, log-differenced terms of trade and oil prices, and energy use per capita. ${ }^{11}$ A priori, these are adequate instruments - especially for small open economies - as cyclical fluctuations are correlated with terms of trade shocks, oil prices and energy use per capita, without being directly influenced by the fiscal stance. For oil exporters, however, we used the lagged value of the output gap, the output gap of the United States, and its lagged value. ${ }^{12}$

The exogenous discretionary policy is calculated as the variability (standard deviation) of a residual $\hat{\zeta}_{t}=C A B_{t}-\hat{\alpha}-\hat{\beta} y_{t}-\hat{\gamma}(C A B)_{t-1}$, where $\hat{\alpha}, \hat{\beta}$, and $\hat{\gamma}$ are obtained from IV estimation. This differs from the standard error of residuals in equation (3), $\sigma_{i}^{\mu}=\sqrt{\operatorname{var}_{i}\left(\hat{\mu}_{t}\right)}$. The reason is that, having instrumented the output gap, the residual of (3) would incorporate the noninstrumented part of the output gap $\left(\hat{\beta}\left(y_{t}-\hat{y}_{t}\right)\right)$, introducing co-movement between our measure of discretionary policy and output gap volatility. This would in turn create a simultaneity bias in the regressions performed to estimate the effect of fiscal policy on output gap variability. By their very nature, these residuals capture more than discretionary policy decisions, including measurement errors, and the direct budgetary impact of certain shocks over and above their influence on economic activity (for instance, exchange rate fluctuations affecting interest payments and commodity-related revenues, the influence of asset prices on certain revenue categories, and inflation shocks). The notion of "exogenous discretionary policy" should therefore be interpreted with caution. While equation (3) could be augmented to account for some of these effects, the measurement of pure shocks raises other issues that would ultimately alter the transparency of our simple approach.

\section{II.1.c. Caveats}

In interpreting our empirical results, one should keep in mind that government size is only an approximation of the cyclical sensitivity of the budget

11. Lee and Sung (2007) estimate the responsiveness of fiscal policy to cyclical fluctuations, taking the average of GDP growth rates in neighboring countries, weighted by the inverse of the distance between the two countries, as an instrument.

12. There are five oil producing countries in the sample. Ideally, the non-oil fiscal balances should be used in the regression. However, no sufficiently long time series were available to obtain meaningful estimates of $\beta$. Dropping these countries from the sample does not alter the results. 
balance. To assess the likelihood of any bias introduced by that proxy, we look at the relation between the public expenditure to GDP ratio and the semi-elasticities of the budget balance to the output gap estimated by the OECD for most of its member countries (Figure 1). These estimates partly take into account the impact of tax progressivity and cyclically-sensitive expenditure. ${ }^{13}$ The regression line is statistically indistinguishable from a 45-degree line, indicating that government size is a reliable proxy of automatic stabilizers in OECD countries.

\section{Figure 1}

\section{Government Size and Cyclical Sensitivity of the Budget Balance (OECD)}

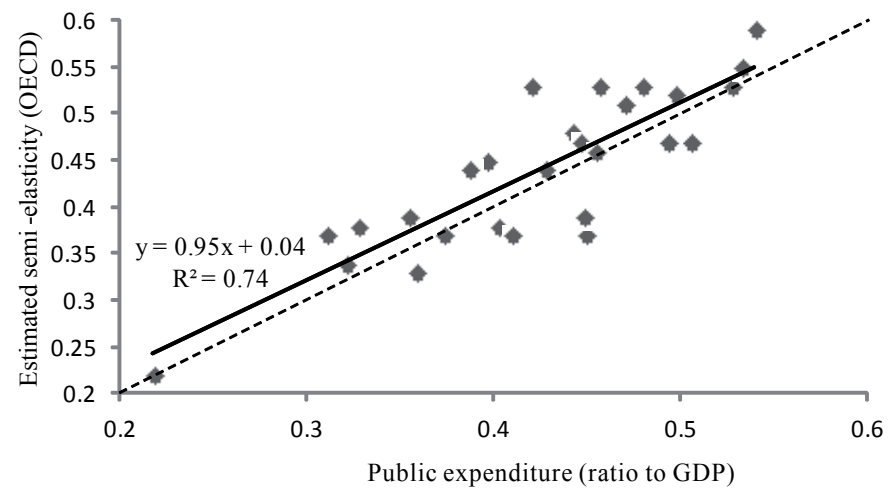

Sources: Girouard and André (2005) and authors' calculations.

Outside the OECD, however, lower output sensitivities may prevail. On the revenue side, a greater share of indirect taxes in revenues and a lower degree of progressivity in direct taxes tend to weaken the responsiveness of tax revenues to income. On the expenditure side, unemployment insurance and other social safety nets are generally less developed. Given this, we may overestimate the size of automatic stabilizers in developing countries, while underestimating their impact on output and consumption volatility. We would correspondingly overestimate the stabilizing influence of cyclical fiscal policy, as $\hat{\beta}$ would capture any measurement error in the size of automatic stabilizers. Another issue is that short time series limit our ability to

13. Some ad-hoc assumptions remain, however, including a unit-elasticity of indirect taxes and a zero-elasticity for expenditure except unemployment benefits. The latter may be a strong assumption in light of Darby and Mélitz (2009) who show that social spending other than unemployment benefits exhibits a significant countercyclicality, including health and pension expenditure. Building on these results, Furceri (2009) estimates that social spending alone is able to offset about 15 percent of output shocks. 
test for the presence of structural breaks in the relation between the $C A B$ and the output gap. In general, tests conducted for OECD countries-for which we have time-series starting in 1970 - do not allow to reject the null hypothesis that $\beta$ is stable between two sub periods (1970-89 and 1990-2006).

\section{II.1.d. Output volatility and automatic stabilizers: stylized facts}

The seminal studies by Gali (1994) and Fatás and Mihov (2001) suggest that the effectiveness of automatic stabilizers is already evident from the negative unconditional correlation between real GDP growth variability and the size of government, and they show this for a sample of selected OECD countries between 1960 and the early 1990s. Our broader sample, which covers selected developing economies and ends in 2006, exhibits a similar correlation (Figure 2, top panel). Subsequent analyses qualified this result, suggesting that the relation is likely to be non-linear and unstable over time. Using the same set of countries as Fatás and Mihov (2001), Debrun, PisaniFerry and Sapir (2008) document a dramatic weakening of the negative relation after the mid 1990s, a stylized fact present in our sample for advanced OECD countries (Figure 2, center panel). Econometric analysis by the same authors also revealed non-linearities in this relation, implying strongly decreasing returns in automatic fiscal stabilization beyond a certain threshold of government size. Silgoner, Reitschuler and Crespo-Cuaresma (2002), and Martinez-Mongay and Sekkat (2005) found similar non-linearities in a sample of EU member states.

Figure 2

Automatic Stabilizers and Output Volatility (1970-2006)

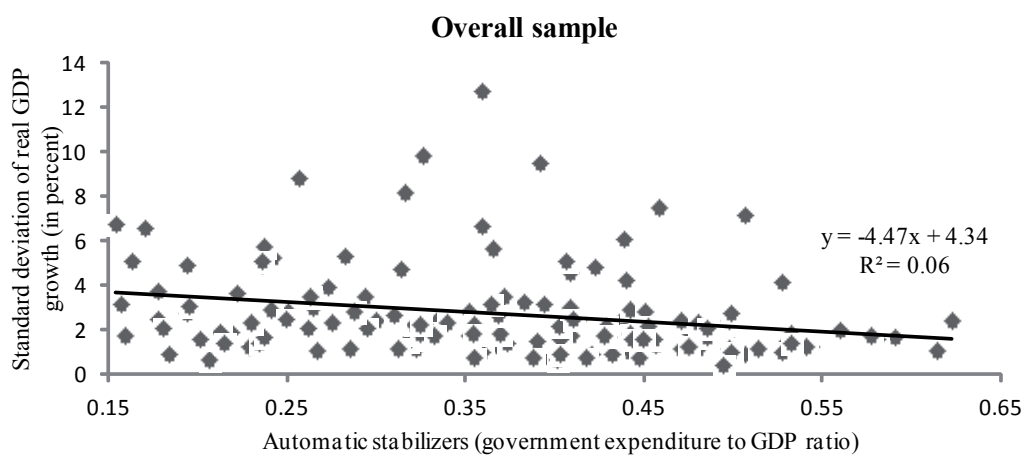



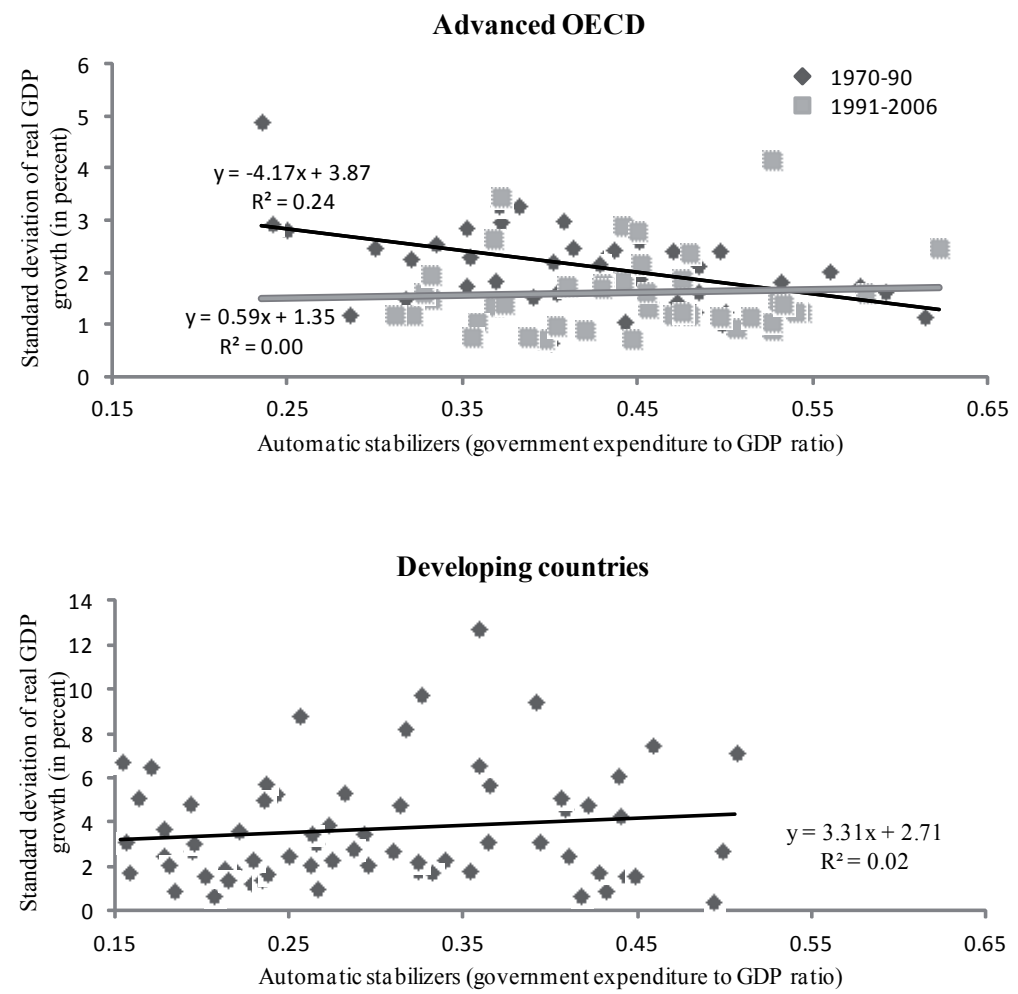

Note: each observation represents a combination of government size and real GDP growth volatility observed in one country over a given decade. Source: Authors' calculations.

Although the literature generally supports the effectiveness of automatic stabilizers in OECD countries, some have suggested that the result may not hold in developing economies. In particular, Viren (2005) finds that the negative relation between government size and GDP volatility does not exist when developing economies are included in the sample. Using our sample, scatter plots indeed depicts a weakly positive correlation for the subset of developing countries (Figure 2, bottom panel).

These stylized facts raise two questions. First, it is unclear why automatic stabilizers per se would be subject to strong "decreasing returns."14 Second, even if government size exaggerates the magnitude of automatic

14. That said, in a reduced-form IS-curve, the relation between output and the size of automatic stabilizers is log-linear because the fiscal impulse stemming from the operation of stabilizers itself depends on output (see the Appendix). 
stabilizers in developing countries, the existence of a positive relationship remains counterintuitive. Both puzzles are consistent with the need to take into account the shock-inducing aspect of fiscal policy. The appearance of decreasing returns could indeed result from the fact that bigger governments generate more destabilizing fiscal shocks, as documented in Debrun and Kapoor (2010). Likewise, the apparent ineffectiveness of automatic stabilizers in developing countries may have to do with more pervasive institutional weaknesses and political economy constraints in these countries that magnify the shock-inducing part of fiscal policy to the point of overcoming automatic stabilizers.

Another interesting characteristic of the relation between output volatility and government size is that it seems to be evolving over time, stressing the importance to examine possible causes for such evolution. Debrun, Pisani-Ferry and Sapir (2008) show that the factors driving the trend decline in output volatility until the recent crisis - the so-called great moderationwere more powerful in countries with smaller government sectors than others. We can verify this in our broader sample and divide countries into 4 categories along 2 dimensions: trade openness and government size (cut-off levels are the median values). We consider only the last two periods of our sample 1990-99 and 2000-06 to cover all the countries.

For both sub-periods, output volatility is on average larger in countries with smaller governments, regardless of trade openness (Figure 3). Rodrik's (1998) observation that more open economies are generally more volatile is verified for 1990-99, but not for the more recent period. Indeed, the bottom panel of Figure 3 shows that the decline in average output volatility between the two subperiods has been more pronounced in more open economies, and among the latter in countries with smaller governments. This suggests that open economies with smaller government took better advantage of the factors driving the great moderation, such as improved access to financial instruments, credit and external financing, allowing economic agents to better smooth consumption and plan investment. Also, openness tends to raise the economic cost of policy mistakes, contributing to better macroeconomic management, including more countercyclical macroeconomic policies. 
Figure 3

\section{Output volatility over time}
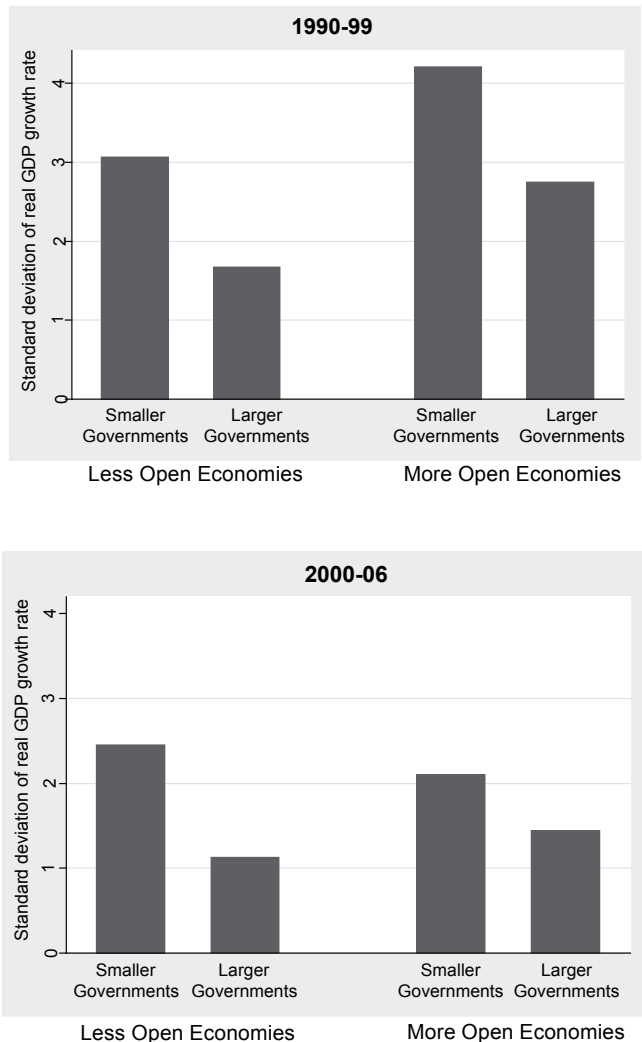

Decline in output volatility over the two periods

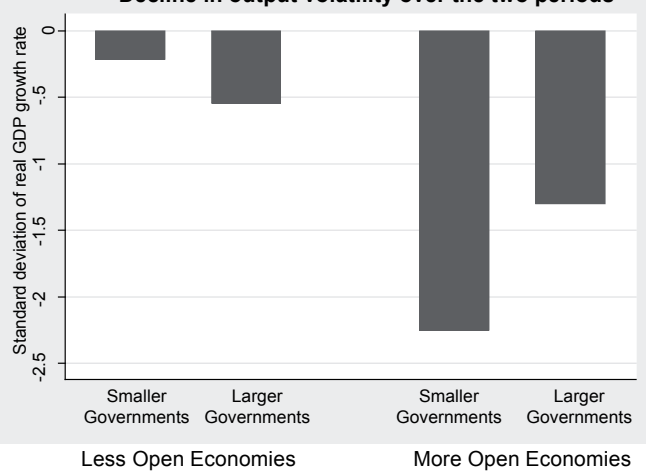

Source: Authors' calculations. 


\section{ECONOMETRIC ANALYSIS}

\section{III.1. Testing the effectiveness of automatic stabilizers}

Following Fatás and Mihov (2001), the empirical test is based on the cross-country relation between government size and output volatility. As we also take into account time-varying factors that may affect the public's demand for fiscal stabilization or the government's incentives to provide such stabilization (Debrun, Pisani-Ferry and Sapir, 2008), the baseline empirical model is a panel regression with period-fixed effects: ${ }^{15}$

$$
Y_{i, t}=\alpha+\sum_{t=2}^{t=4} \lambda_{t} P_{t}+\phi_{1} G_{i, t}+\phi_{2} C y c_{i}+\phi_{3} \text { Discr }_{i, t}+\sum_{j=1}^{J} \theta_{j} X_{j, i, t}+v_{i, t},
$$

with $i=1, \ldots .49$ (countries) and $i=1, \ldots 4$ (10-year period). $Y_{i, t}$ is a measure of real GDP volatility, the $P_{t}$ 's symbolize period fixed effects, $G_{i, t}$ denotes the size of automatic stabilizers (logarithm of public expenditure in percent of GDP), $C y c_{i}$ and Discr $_{i, t}$ are the cyclical and discretionary dimensions of fiscal policy discussed in section 1 , the $X_{j}^{\prime}$ 's are control variables, and $v_{i, t}$ is the error term. As the cyclicality indicator is an estimated coefficient, it is sometimes not statistically different from zero. To reduce the noise stemming from such uncertainty, we set $C y c_{i}$ equal to zero for countries where the $\hat{\beta}_{i}$ is statistically insignificant at the 10 percent confidence level. The discretionary dimension Discr $_{i, t}$ is calculated for each subperiod to capture any change in the average magnitude of fiscal policy shocks non-systematically related to the business cycle.

By default, we calculate output volatility as the standard deviation of real GDP growth over each period $t$. However, since this measure is sensitive to variations in potential growth (over time and across countries), we systematically checked the robustness of our results using the standard deviation of the first differenced output gap (calculated by us for all countries as the relative difference between actual real GDP and its HP-filtered series). The focus on aggregate output volatility - instead of privately-generated GDP for instance - is justified by the fact that the contribution of fiscal policy to macroeconomic stability also operates through composition effects of national expenditure (Andrés, Doménech and Fatàs, 2008). Although there is

15. The time dimension comprises 4 periods over which annual data have been averaged (197079, 1980-89, 1990-99 and 2000-06). The panel is unbalanced because of data limitations for developing and emerging market economies. The Appendix reports data sources. Input from auxiliary regressions can be found in Debrun and Kapoor (2010). 
no evident theoretical reason for rejecting these effects, we also investigated the relationship between our fiscal indicators and the variability of private consumption because the latter is more directly related to welfare.

A rejection of the null hypothesis that $\phi_{1}=0$ against the alternative $\phi_{1}<0$ is consistent with the effectiveness of automatic stabilizers. The Appendix formally illustrates that, given a sample average of 0.38 for government size, plausible values of $\phi_{1}$ lie between -0.5 and -2.6. As we have more observations than most comparable studies, we are better placed to deal with the omitted-variables and reverse causality issues inherent to a single-equation approach. More specifically, we introduce determinants of volatility that have been related to the "great moderation" episode and are suspected to have weakened the relation between government size and output volatility. We then we assess the robustness of our results, and expand the analysis to private consumption volatility.

\section{III.2 Fiscal policy: shock-absorbing or shock-inducing?}

We first estimate a parsimonious model deliberately omitting discretionary and cyclical dimensions of fiscal policy as well as time-series determinants of output volatility (Table 1). The results are consistent with two stylized facts noted earlier. First, non-OECD-20 countries are both more volatile and have smaller governments, explaining why the standard stabilization result holds for the whole sample but not for the non-OECD-20 subset. Second, among the OECD-20 group, the effectiveness of automatic stabilizers seems to have decreased substantially over the last two decades.

We conjectured earlier that omitting Discr $_{i, t}$ could entail a serious upward bias in estimates of $\phi_{1}$ if bigger governments also tended to induce larger shocks. The results summarized in Table 2 -which now include all dimensions of fiscal policy and the time-series controls-lend support to that hypothesis: the size of government now has a negative and statistically significant impact on output volatility, and this regardless of whether we restrict the sample to certain economies or sub-periods. The absolute values of $\hat{\phi}_{1}$ are higher than previously estimated, and the confidence intervals are narrower. They are also quantitatively similar to Fatás and Mihov (2001) around 2 - despite a very different sample. 
Table 1

A parsimonious model

\begin{tabular}{l|cccc}
\multirow{3}{*}{ Dependent Variable } & \multicolumn{4}{c}{ STANDARD DEVIATION OF REAL GDP GROWTH RATE } \\
\cline { 2 - 5 } & All & $\begin{array}{c}\text { Non- } \\
\text { OECD }\end{array}$ & $\begin{array}{c}\text { OECD } \\
(\mathbf{1 9 7 0 - 8 9 )}\end{array}$ & $\begin{array}{c}\text { OECD } \\
(\mathbf{1 9 9 0 - 2 0 0 6 )}\end{array}$ \\
\hline \multirow{3}{*}{ Openness } & 1 & 2 & 3 & 4 \\
Automatic Stabilizers & 1.143 & 0.150 & $1.617 *$ & 0.720 \\
& $(1.32)$ & $(0.11)$ & $(1.87)$ & $(1.17)$ \\
Constant & $-1.614 * * *$ & 1038 & $-2.224 * *$ & -0.244 \\
& $(-4.45)$ & -1.35 & $(-2.78)$ & $(-0.41)$ \\
Observations & 0.728 & $5.614^{* * *}$ & -0.418 & 0.675 \\
R -squared & -1.21 & -3.19 & $(-0.48)$ & -0.99 \\
\hline
\end{tabular}

Note: Robust t-statistics in parentheses. Time effects are not reported. Stars denote statistical significance at conventional levels (* for 10 per cent, $* *$ for 5 per cent, and $* * *$ for 1 per cent).

Table 2

Introducing Cyclical and Discretionary Dimensions of Fiscal Policy (Dependent variable: standard deviation of real GDP growth rate)

\begin{tabular}{l|cccccc}
$\begin{array}{l}\text { Dependent } \\
\text { Variable }\end{array}$ & OECD-20 & $\begin{array}{c}\text { Non } \\
\text { OECD-20 }\end{array}$ & All & All & All & All \\
& & & & $1970-89$ & $1990-2006$ & \\
\hline & 1 & 2 & 3 & 4 & 5 & 6 \\
\hline Openness & 0.717 & 0.462 & 0.507 & -0.389 & 0.684 & 0.519 \\
& $(1.56)$ & $(0.48)$ & $(0.79)$ & $(-0.33)$ & $(1.00)$ & $(0.86)$ \\
Automatic & $-1.409^{* * *}$ & $-1.605^{*}$ & $-2.013^{* * *}$ & $-1.290^{* *}$ & $-2.257^{* * *}$ & $-1.680^{* * *}$ \\
Stabilizers & $(-2.93)$ & $(-1.79)$ & $(-5.00)$ & $(-2.30)$ & $(-3.89)$ & $(-4.21)$ \\
Central Bank & -0.117 & 0.715 & $1.096^{*}$ & 0.138 & 1.404 & $-2.728^{* * *}$ \\
Independence & $(-0.27)$ & $(0.47)$ & $(1.79)$ & $(0.18)$ & $(1.63)$ & $(-2.62)$ \\
Financial & $-0.446^{*}$ & -0.01 & $-0.788^{* * *}$ & -0.577 & $-0.770^{* *}$ & $-0.550^{* *}$ \\
Development & $(-1.98)$ & $(-0.02)$ & $(-3.01)$ & $(-1.08)$ & $(-2.56)$ & $(-2.20)$ \\
Cyclical & -0.065 & 0.209 & 0.114 & -0.214 & 0.030 & 0.026 \\
Fiscal Policy & $(-0.27)$ & $(0.15)$ & $(0.38)$ & $(-0.51)$ & $(0.07)$ & $(0.09)$ \\
Discretionary & 0.016 & $0.911 * * *$ & $0.672^{* * *}$ & 0.186 & $0.877^{* * *}$ & $-0.451^{*}$ \\
Fiscal Policy & $(0.16)$ & $(4.62)$ & $(4.64)$ & $(1.19)$ & $(4.66)$ & $(-1.79)$ \\
Interaction: & $\ldots$ & $\ldots$ & $\ldots$ & $\ldots$ & $\ldots$ & $2.118^{* * *}$ \\
Discretion x CBI & & & & & & $(3.83)$ \\
Constant & $1.013^{* *}$ & -2.501 & -1.134 & 0.992 & $-2.617^{* *}$ & $\ldots$ \\
& $(2.13)$ & $(-1.17)$ & $(-1.51)$ & $(0.42)$ & $(-2.42)$ & $\ldots$ \\
\hline Observations & 77 & 56 & 133 & 47 & 86 & 133 \\
R -squared & 0.40 & 0.52 & 0.50 & 0.35 & 0.57 & 0.58 \\
\hline
\end{tabular}

Note: Robust t-statistics in parentheses. Time effects are not reported. Stars denote statistical significance at conventional levels $(*$ for 10 per cent, $* *$ for 5 per cent, and $* * *$ for 1 per cent). 
These results differ from Fatás and Mihov (2003) who find that government size has a positive effect on volatility in a cross-section of 91 countries. Their model is similar to (4) except that (i) they have no measure of $C y c_{i}$, (ii) the time dimension is missing, and (iii) their measure of Discr $_{i, t}$ is based on public consumption only. Two important reasons for the difference are that our approach allows for a richer set of relevant determinants of volatility (e.g. financial development) and that it uses measures of automatic stabilizers, cyclical policy and discretionary policy that are mutually consistent and based on a broad coverage of the government sector.

While we fail to find any significant stabilizing impact of the cyclical dimension (a sign that this series may be too noisy), the coefficient $\hat{\phi}_{3}$ on the discretionary dimension is positive and significant for the unrestricted sample and for the sub-sample excluding the OECD-20. In contrast, $\hat{\phi}_{3}$ is not significantly different from zero in the OECD-20. Also, the fit of the model increases substantially. These results suggest that discretionary fiscal policy is likely to be an important contributor to output volatility outside the core OECD economies covered in previous studies. This is in line with Fatás and Mihov (2003), although our measure of discretionary policy_-based on budget balance volatility - is quite different from theirs - volatility of GDPgrowth-adjusted public consumption.

An interesting observation is that the degree of central bank independence has a significantly positive impact on volatility, a result largely driven by the presence of the non-OECD-20 countries in the sample. This could suggest that anti-inflationary credentials take time to build up despite rising degrees of legal independence, or that productivity shocks and decision lags entail a meaningful trade-off between real and nominal stability.

Another possibility is that coordination failures in the policy mix could be more frequent when monetary and fiscal authorities independently pursue different objectives. Specifically, fiscal impulses unrelated to routine stabilization are more likely to lead to costly conflicts with monetary authorities when the latter are politically independent than when they are forced to accommodate fiscal shocks. To explore that conjecture, we added to the model an interaction term between the index of central bank independence (CBI) and our measure of exogenous fiscal policy. In the presence of the interaction term, the estimated coefficient of CBI turns negative and significant - as one would expect if CBI induces improvements in the quality of monetary policy - whereas the interaction term is positive and 
highly significant. One interpretation is that fiscal impulses not systematically related to output stabilization undermine the benefits of central bank independence, reflecting possible coordination failures in the policy mix.

The fact that $\hat{\phi}_{3}$ also turns negative when the interaction term is present could indicate that such conflicts would be the main reason for the positive conditional correlation between fiscal discretion and output volatility.

Finally, we see that the moderating impact of financial development on output volatility is robust to the introduction of our fiscal controls although that effect is mainly driven by more recent (post-1990) observations.

\section{III.3 Robustness checks}

We now check the robustness of our results to common econometric issues, first examining the possibility of reverse-causality, and then assessing the risk of an omitted-variable bias.

\section{III.3.a Endogeneity}

Equations (4) and (5) are potentially subject to reverse causality problems. For instance, governments concerned with output stability could arguably adjust their fiscal behavior and the size of automatic stabilizers to the intensity of exogenous disturbances affecting the economy (Rodrik, 1998). Reverse causality could also bias estimated coefficients on CBI and financial development if more volatile economies are more inclined to delegate monetary policy to an independent agency with a clear stabilization mandate, and if private agents take better advantage of financial services to self-insure against the income effect of aggregate fluctuations.

Following Fatás and Mihov (2001, 2003), we selected instruments capturing institutional and structural characteristics of countries likely to be correlated with our explanatory variables but presumably orthogonal to output volatility itself. Institutional instruments include the electoral rule (proportional vs. majoritarian), the type of political system (presidential vs. parliamentary), the presence of political constraints (number of veto points in the government), and the distribution of ideological preferences. Other instruments are GDP per capita (at PPP, in log), the dependency ratio, the rate of urbanization, and a dummy variable identifying oil producers. 
Table 3

Two-Stage-Least-Squares (2SLS) Estimates (Dependent variable: standard deviation of real GDP growth rate)

\begin{tabular}{|c|c|c|c|c|c|}
\hline Instrumented Variable & $\begin{array}{l}\text { Automatic } \\
\text { Stabilizers }\end{array}$ & $\begin{array}{l}\text { Cyclical } \\
\text { Fiscal } \\
\text { Policy }\end{array}$ & $\begin{array}{l}\text { Discretion- } \\
\text { ary Fiscal } \\
\text { Policy }\end{array}$ & $\begin{array}{c}\text { Financial } \\
\text { Development }\end{array}$ & $\begin{array}{c}\text { Central } \\
\text { Bank Inde- } \\
\text { pendence }\end{array}$ \\
\hline & 1 & 2 & 3 & 4 & 5 \\
\hline Openness & $\begin{array}{l}0.528 \\
(0.83)\end{array}$ & $\begin{array}{l}0.472 \\
(0.75)\end{array}$ & $\begin{array}{l}0.491 \\
(0.74)\end{array}$ & $\begin{array}{l}0.539 \\
(0.85)\end{array}$ & $\begin{array}{l}0.566 \\
(0.79)\end{array}$ \\
\hline $\begin{array}{l}\text { Automatic } \\
\text { Stabilizers }\end{array}$ & $\begin{array}{c}-2.271 * * * \\
(-4.17)\end{array}$ & $\begin{array}{l}-2.169^{* * *} \\
(-5.11)\end{array}$ & $\begin{array}{c}-1.948^{* * *} \\
(-4.07)\end{array}$ & $\begin{array}{l}-2.144 * * * \\
(-5.00)\end{array}$ & $\begin{array}{c}-2.802 * * * \\
(-4.31)\end{array}$ \\
\hline $\begin{array}{l}\text { Central Bank } \\
\text { Independence }\end{array}$ & $\begin{array}{r}1.096^{*} \\
(1.69)\end{array}$ & $\begin{array}{r}1.050^{*} \\
(1.75)\end{array}$ & $\begin{array}{l}0.790 \\
(1.23)\end{array}$ & $\begin{array}{r}1.084^{*} \\
(1.80)\end{array}$ & $\begin{array}{r}3.873^{*} \\
(1.85)\end{array}$ \\
\hline $\begin{array}{l}\text { Financial } \\
\text { Development }\end{array}$ & $\begin{array}{c}-0.817 * * * \\
(-3.21)\end{array}$ & $\begin{array}{l}-0.814 * * * \\
(-3.14)\end{array}$ & $\begin{array}{l}-0.971 * * * \\
(-3.45)\end{array}$ & $\begin{array}{l}-1.083^{* * *} \\
(-2.61)\end{array}$ & $\begin{array}{l}-0.902 * * * \\
(-3.25)\end{array}$ \\
\hline Cyclical Fiscal Policy & $\begin{array}{l}0.125 \\
(0.44)\end{array}$ & $\begin{array}{l}0.012 \\
(0.01)\end{array}$ & $\begin{array}{l}-0.225 \\
(-0.75)\end{array}$ & $\begin{array}{l}0.166 \\
(0.57)\end{array}$ & $\begin{array}{l}0.099 \\
(0.29)\end{array}$ \\
\hline Discretionary Fiscal Policy & $\begin{array}{c}0.671 * * * \\
\quad(4.22)\end{array}$ & $\begin{array}{c}0.659 * * * \\
(3.64)\end{array}$ & $\begin{array}{l}0.322 \\
(0.87)\end{array}$ & $\begin{array}{c}0.650^{* * * *} \\
(4.15)\end{array}$ & $\begin{array}{c}0.734 * * * \\
(4.92)\end{array}$ \\
\hline Constant & $\begin{array}{l}-1.201 \\
(-1.31)\end{array}$ & $\begin{array}{l}-1.037 \\
(-1.32)\end{array}$ & $\begin{array}{l}-0.063 \\
(-0.06)\end{array}$ & $\begin{array}{l}-0.896 \\
(-1.24)\end{array}$ & $\begin{array}{l}-3.070^{*} \\
(-1.86)\end{array}$ \\
\hline Observations & 127 & 127 & 127 & 127 & 127 \\
\hline $\mathrm{R}$-squared & 0.49 & 0.49 & 0.44 & 0.48 & 0.39 \\
\hline $\begin{array}{l}\text { Wu-Hausman Test } \\
\text { (p -value) }\end{array}$ & 0.79 & 0.92 & 0.05 & 0.31 & 0.11 \\
\hline Hansen J Test (p -value) & 0.24 & 0.25 & 0.41 & 0.38 & 0.37 \\
\hline $\begin{array}{l}\text { Weak Identification } \\
\text { (F-stat) }\end{array}$ & $27.76^{* *}$ & 3.4 & 7.65 & $24.41 * *$ & 2.55 \\
\hline \multicolumn{6}{|l|}{$\begin{array}{l}\text { Exogeneity Tests } \\
\text { (p -value): }\end{array}$} \\
\hline Automatic Stabilizers & $\cdots$ & 0.9 & 0.72 & 0.75 & 0.53 \\
\hline Central Bank Independence & 0.3 & 0.1 & 0.64 & 0.1 & $\ldots$ \\
\hline Financial Development & 0.26 & 0.15 & 0.16 & $\ldots$ & 0.07 \\
\hline Discretionary Fiscal Policy & 0.13 & 0.07 & $\cdots$ & 0.34 & 0.26 \\
\hline Cyclical Fiscal Policy & 0.04 & $\cdots$ & 0.26 & 0.1 & 0.25 \\
\hline
\end{tabular}

Note: Robust t-statistics in parentheses. Time effects are not reported. Stars denote statistical significance at conventional levels (* for 10 per cent, ** for 5 per cent, and *** for 1 per cent). 
The specification used for 2SLS estimation is column (3) of Table 2. We instrumented potentially endogenous explanatory variables one by one, each time testing for the endogeneity of other suspicious instruments. ${ }^{16}$ Formal exogeneity tests (Wu-Hausman-WH) only rejected the null hypothesis that OLS estimates are consistent for $\operatorname{Discr}_{i, t}$ (strongly) and the index of central bank independence (marginally), suggesting that 2SLS should be preferred over OLS (column (3) and (5) of Table 3). Testing for the orthogonality between each non-instrumented explanatory variable (i.e. the included instruments) and the error term broadly support the conclusions of the WH tests.

Two-stage least-squares estimates confirm the effectiveness of automatic stabilizers (column (1) of Table 3) and the stabilizing impact of financial development (column (4)), although the coefficient for the latter is somewhat higher in absolute value. The other results are difficult to interpret because instruments appear to be weak, meaning that the explanatory power of the excluded instruments in the first stage regression is too low to provide reliable identification. Hence 2SLS estimators are biased and inefficient, especially in small samples such as ours (Stock, Wright and Yogo, 2002). It is nevertheless notable that our indicator of fiscal policy discretion does not appear to significantly raise volatility when it is instrumented. This could be a sign that this indicator also reflects other sources of output volatility not captured by the statistical model, but with potentially significant budgetary consequences (e.g. commodity or asset prices, exchange rates, inflation shocks...).

\section{III.3.b Omitted variables}

The omission of relevant explanatory variables could also entail a correlation between the error term and the independent variables. We thus further examine the possibility of a bias by adding potential determinants of output volatility to the baseline specification. Keeping our focus on the effectiveness of automatic stabilizers, we follow Fatás and Mihov (2001) and select controls likely to be correlated with both government size and output volatility. ${ }^{17}$ None of the added explanatory variable turns out being statistically significant (neither individually nor together, as shown in Table 4), and estimates of the coefficients of interest (automatic stabilizers, discretionary fiscal policy and financial development) are not statistically different across regressions.

16. Instrumenting multiple right-hand-side variables did not yield any meaningful result, in large part reflecting the weak-instrument issue discussed below.

17. These authors discuss in detail the motivation for each of those controls. 


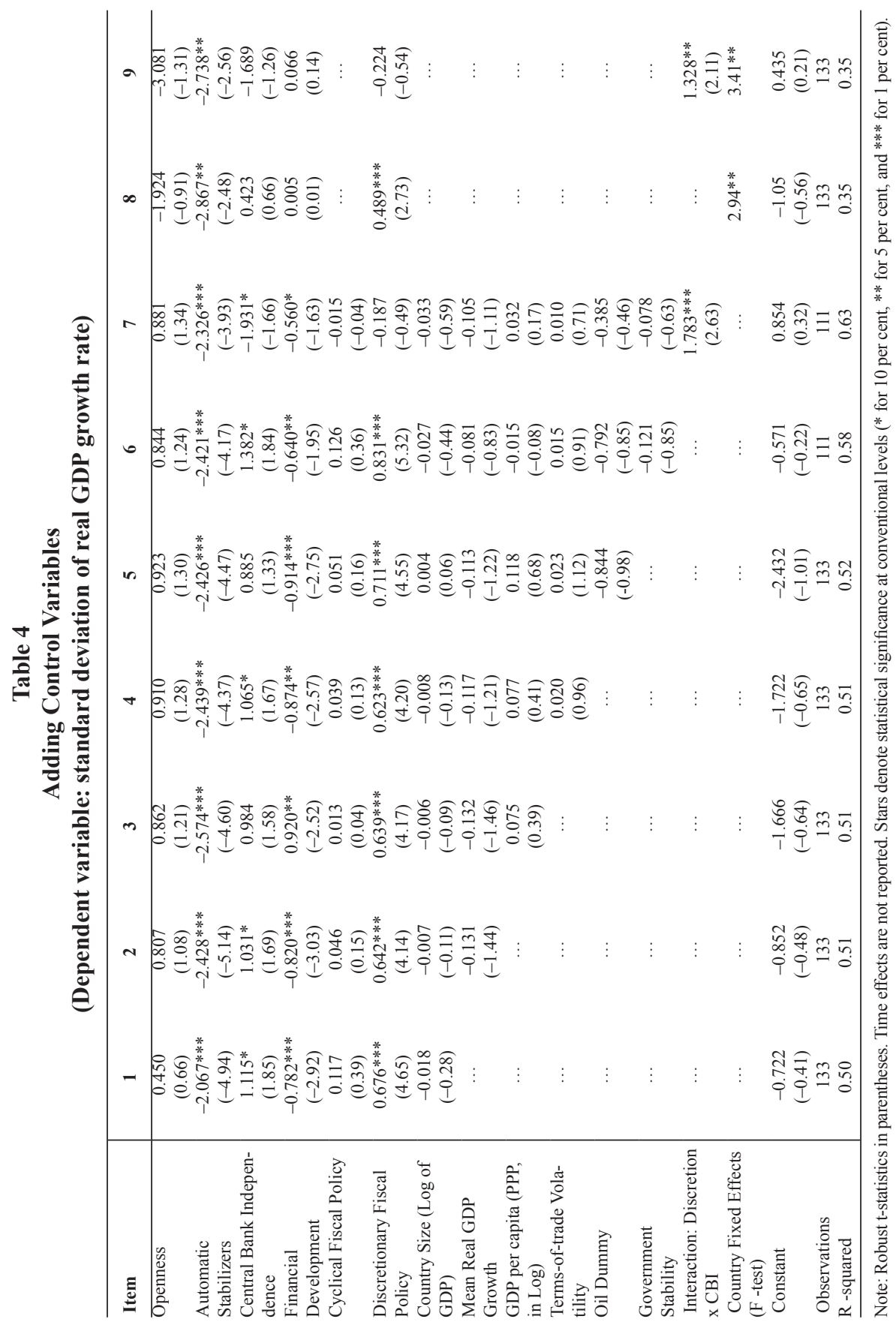


In a panel context, a natural test for the robustness of our results to omitted variables is to add country fixed-effects. The limited size of our sample limits our investigation to the parsimonious specifications in columns (8) and (9), which exclude the cyclical policy indicator because it has no time-series variance. The stabilizing impact of financial development does not survive this "acid test," pointing to the possibility that some underlying, country-specific variables — perhaps "deep" institutional determinants ${ }^{18}$ — jointly determine the level of financial development and macroeconomic volatility. In contrast, automatic stabilizers and discretionary policy still exhibit respectively stabilizing and destabilizing impacts on GDP growth. The interaction between CBI and discretionary fiscal policy passes the test as well, adding support to the possibility that coordination failures in the policy mix could be a key channel through which fiscal discretion increases output volatility.

\section{III.3.c Fiscal policy and private consumption volatility}

While macroeconomic stabilization aims at reducing the volatility of output, welfare gains are often thought to be more closely associated with the stability of real private consumption. ${ }^{19}$ Although output and consumption (real growth) volatilities are strongly correlated (unconditional correlation coefficient of 0.69 in our sample), the determinants of private consumption reflect individual choices that may be more directly responsive to opportunities to smooth consumption than to fiscal aggregates. Variancedecomposition exercises performed by Debrun, Pisani-Ferry and Sapir (2008) provide some support to that presumption, showing that automatic stabilizers - income tax payments and transfers-have not contributed to the decline in consumption volatility observed since the mid-1980s.

To model private consumption volatility, we follow equation (4). The results are qualitatively comparable to those found for output volatility, but with important nuances (Table 5). First, the stabilizing effect of financial development is quantitatively large and statistically significant, confirming the important role of access to credit in providing consumption-smoothing opportunities to consumers. Second, automatic stabilizers continue to play a stabilizing role, although it is quantitatively smaller than for output (by roughly $1 / 2$ in most regressions) and less precisely estimated. Instrumenting government size yields quantitatively similar results to the output volatility equation.

18. See Acemoglu and others (2002).

19. The argument is not so clear-cut, however, because output fluctuations are likely to be more tightly related to employment, and thereby leisure. 
Table 5

Fiscal Policy and Consumption Volatility (dependent variable: standard deviation of real GDP growth rate)

\begin{tabular}{|c|c|c|c|c|c|c|}
\hline \multirow[t]{2}{*}{ Estimator: } & \multicolumn{2}{|c|}{ OLS } & \multicolumn{4}{|c|}{ 2SLS } \\
\hline & $\cdots$ & $\cdots$ & $\begin{array}{l}\text { Automatic } \\
\text { Stabilizers }\end{array}$ & $\begin{array}{c}\text { Cyclical } \\
\text { Fiscal } \\
\text { Policy }\end{array}$ & $\begin{array}{c}\text { Discre- } \\
\text { tionary } \\
\text { Fiscal } \\
\text { Policy }\end{array}$ & $\begin{array}{c}\text { Financial } \\
\text { Develop- } \\
\text { ment }\end{array}$ \\
\hline $\begin{array}{l}\text { Instrumented } \\
\text { Variable: }\end{array}$ & 1 & 2 & 3 & 4 & 5 & 6 \\
\hline \multirow[t]{2}{*}{ Openness } & 1032 & 1059 & 1417 & 1050 & 1227 & 1.348 \\
\hline & (1.11) & (1.19) & $(1.59)$ & $(1.10)$ & $(1.28)$ & -1.43 \\
\hline Automatic & $-1.140 *$ & -0.772 & $-2.046^{* * *}$ & $-1.307 * *$ & $-1.091 *$ & $-1.263 * *$ \\
\hline Stabilizers & $(-1.94)$ & $(-1.36)$ & $(-2.61)$ & $(-2.08)$ & $(-1.63)$ & $(-1.99)$ \\
\hline Central Bank & 0.944 & $-2.886^{*}$ & 1637 & 1289 & 0.958 & 1.375 \\
\hline Independence & $(1.08)$ & $(-1.86)$ & $(1.62)$ & $(1.51)$ & $(1.08)$ & -1.58 \\
\hline Financial & $-1.429 * * *$ & $-1.196 * * *$ & $-1.394 * * *$ & $-1.384 * * *$ & $-1.633 * * *$ & $-2.228 * * *$ \\
\hline Development & $(-2.94)$ & $(-2.42)$ & $(-3.15)$ & $(-3.13)$ & $(-3.23)$ & $(-2.91)$ \\
\hline \multirow{2}{*}{$\begin{array}{l}\text { Cyclical } \\
\text { Fiscal Policy }\end{array}$} & -0.511 & -0.606 & -0.387 & -1.11 & $-0.875^{*}$ & -0.318 \\
\hline & $(-1.15)$ & $(-1.43)$ & $(-0.87)$ & $(-0.88)$ & $(-1.81)$ & $(-0.70)$ \\
\hline \multirow{2}{*}{$\begin{array}{l}\text { Discretionary } \\
\text { Fiscal Policy }\end{array}$} & $0.525 * * *$ & $-0.606^{*}$ & $0.611 * * *$ & $0.526^{* *}$ & 0.162 & $0.521 * *$ \\
\hline & $(2.51)$ & $(-1.89)$ & $(2.84)$ & $(2.04)$ & $(0.39)$ & -2.39 \\
\hline Interaction: & $\cdots$ & $2.118 * * *$ & $\cdots$ & $\cdots$ & $\cdots$ & $\cdots$ \\
\hline Discretion $\mathrm{x}$ CBI & & $(2.76)$ & & & & \\
\hline \multirow[t]{2}{*}{ Constant } & 0.307 & $2.575 * *$ & -1.028 & 0.168 & 1210 & 0.514 \\
\hline & $(0.28)$ & $(2.25)$ & $(-0.80)$ & $(0.13)$ & $(0.78)$ & -0.44 \\
\hline Observations & 131 & 131 & 126 & 126 & 126 & 126 \\
\hline R -squared & 0.35 & 0.39 & 0.35 & 0.35 & 0.33 & 0.34 \\
\hline $\begin{array}{l}\text { Wu-Hausman } \\
\text { Test (p -value) }\end{array}$ & $\cdots$ & $\cdots$ & 0.24 & 0.65 & 0.14 & 0.06 \\
\hline $\begin{array}{l}\text { Hansen J Test } \\
\text { (p-value) }\end{array}$ & $\cdots$ & $\cdots$ & 0.16 & 0.12 & 0.17 & 0.34 \\
\hline $\begin{array}{l}\text { Weak Identifica- } \\
\text { tion (F -stat) }\end{array}$ & $\ldots$ & $\cdots$ & $27.14 * *$ & 3.37 & 7.44 & $23.49 * *$ \\
\hline
\end{tabular}

Note: Robust t-statistics in parentheses. Time effects are not reported. Stars denote statistical significance at conventional levels (* for 10 per cent, $* *$ for 5 per cent, and *** for 1 per cent). 
However, these results are not robust to the introduction of additional control variables, even though the latter remain non-significant. Third, the discretionary dimension of fiscal policy is generally destabilizing; but simultaneity concerns remain. Fourth, the cyclical dimension of fiscal policy now consistently has the expected negative impact on consumption volatility although large estimation errors ${ }^{20}$ remain. Still, the contrast with the output equations is striking enough to suggest that systematic stabilizing actions by fiscal policymakers seem to be more effective at stabilizing private consumption, possibly because they are better targeted. Alternatively, this could indicate that our indicator of cyclical fiscal policy also captures automatic stabilizers on the expenditure side, which are by design targeted at smoothing individual consumer income. Finally, the interaction between the $\mathrm{CBI}$ index and our measure of the discretionary dimension of fiscal policy remains strong and statistically significant.

\section{Conclusions}

This paper revisits the empirical link between fiscal policy and macroeconomic volatility (output and private consumption). Our analysis is based on a sample of 49 developing and advanced economies spanning the last 40 years. Results generally provide strong support for the view that fiscal stabilization operates mainly through automatic stabilizers. By contrast, fiscal policies systematically linked to cyclical conditions-be they pro- or counter-cyclical - do not appear to have a meaningful impact on output volatility. Finally, fiscal variability not systematically related to the business cycle generally seems to increase output and consumption volatility, possibly due in part to conflicts with monetary authorities. However, these latter two results may suffer from a simultaneity bias because certain sources of budgetary volatility (e.g. exchange rate, or inflation) are correlated with output volatility. Outside fiscal policy, financial development seems to exert a moderating influence on income and, even more so, on consumption growth, but robustness analysis indicates that it may proxy the role of other countryspecific features not included in our analysis. As regards monetary policy, central bank independence is associated with lower volatility, provided that the interaction between monetary and fiscal policies is taken into account.

20. Running the same regressions with the unrestricted indicator of cyclical policy indeed reduces $\hat{\phi}_{2}$ and increases errors. 
The analysis contributes to the relevant literature in two ways. First, we show that the effectiveness of automatic stabilizers extends well beyond the narrow sample of 20 OECD countries explored by Fatás and Mihov (2001) and apply with equal strength to a broader set of highly heterogeneous countries, including developing economies. Second, our robustness tests strike a note of caution on the causal nature of the relationship between discretionary policy activism and output volatility (Fatás and Mihov, 2003).

Broader policy implications emerge. First, fiscal policy is unambiguously effective at durably stabilizing the economy when it operates in the same way as automatic stabilizers (in a timely, reasonably predictable and symmetric way). Second, governments could also contribute to macroeconomic stability by subjecting the pursuit of other objectives (redistribution or efficiency) to a "stability test." Our results indeed suggest that a conscious effort to reduce conflicts among public finance objectives and between monetary and fiscal policies could reduce output volatility. One practical way to do so is to subject budget preparation to quantitative objectives or even binding constraints defined in terms of a structural balance or expenditure ceilings.

That said, an exclusive reliance on automatic stabilizers as the channel of fiscal stabilization has limits and potential drawbacks. In terms of the limits, recent experience suggests that government revenues endogenously respond to asset price cycles not necessarily synchronized with the business cycle. The induced swings in commonly estimated structural budget balances may be difficult to sustain politically, leading to pro-cyclical fiscal expansions when structural surpluses appear substantial (Alesina, 2000). Also, automatic stabilizers may be insufficient in case of acute crises, or when other policy instruments or consumption smoothing opportunities are constrained.

In terms of the drawbacks, the fact that large stabilizers come with large government sectors may adversely affect potential growth and the economy's resilience to shocks; and as our analysis suggests, it could also increase the likelihood of destabilizing fiscal shocks. In light of these limits and drawbacks, a number of proposals to enhance fiscal stabilizers without increasing the size of government have been made. For instance, given the difficulty to design effective fiscal stimulus plans and the incomplete credibility of subsequent consolidations, automatic adjustments in selected tax rates or expenditure programs could be envisaged (see Baunsgaard and Symansky, 2009, for a survey and an assessment). 
Looking forward, further research will need to address a number of pending issues. First, we see a need to explore more systematically the apparently strong impact of monetary-fiscal conflicts on macroeconomic volatility, as this could have important implications for the design of macro-fiscal frameworks. In particular, alternative measures of the quality of monetary policy should be envisaged. Second, we ignored the impact of expenditure and revenue composition on the size of fiscal stabilizers, possibly introducing measurement errors. Third, and related, more work is needed to improve measures of automatic stabilizers - particularly to have a better grasp of the role of expenditure composition - and of fiscal discretion.

\section{REFERENCES}

Acemoglu,Daron, SimonJohnson,JamesRobinson, and Yunyong Thaicharoen (2002), "Institutional Causes, Macroeconomic Symptoms: Volatility, Crisis and Growth," manuscript, MIT, Cambridge, MA.

Afonso, Antonio, Luca Agnello, and Davide Furceri (2009), "Fiscal policy responsiveness, persistence, and discretion," Public Choice, forthcoming.

Alesina, Alberto (2000), "The political economy of the budget surplus in the US," Journal of Economic Perspectives 14, 3-19.

Alesina, Alberto and Guido Tabellini (2005), "Why is fiscal policy often procyclical?” NBER Working Papers No 11600.

Andrés, Javier, Rafael Doménech, and Antonio Fatás (2008), "The stabilizing role of government size," Journal of Economic Dynamics and Control 32, 571-93.

Baunsgaard, Thomas and Steven Symansky (2009), "Automatic fiscal stabilizers," IMF Staff Position Note No 09/23.

Beck, Thorsten, George Clarke, Alberto Groff, Philip Keefer, and Patrick Walsh (2001), "New tools in comparative political economy: the database of political institutions," World Bank Economic Review 15, 165-76.

Beetsma, Roel, Xavier Debrun, and Frank Klaassen (2001), "Is fiscal policy coordination in EMU desirable?" Swedish Economic Policy Review 8, 57-98.

Berger, Helge, and Ulrich Woitek (2005), "Does conservatism matter? A time-series approach to central bank behaviour", The Economic Journal 115, 745-66. 
Blanchard, Olivier (2000), “Commentary,” Economic Policy Review, April, (New York: Federal Reserve Bank of New York).

Blanchard, Olivier and Roberto Perotti (2002), "An empirical characterization of the dynamic effects of changes in government spending and taxes on output," Quarterly Journal of Economics 117, 609-57.

Blinder, Alan, and Robert Solow (1974), “Analytical Foundations of Fiscal Policy," in The Economics of Public Finance, (Washington, D.C: The Brookings Institution).

Botman, Dennis, Douglas Laxton, Dirk Muir, and Andrei Romanov (2006), "A new-open-economy macro model for fiscal policy evaluation," IMF Working Paper No 06/45.

Bouthevillain, Carine, Philippine Cour-Thimann, Pablo Hernandez Cos, Matthias Mohr, Mika Tujula, Geert Langenus, Sandro Momigliano and Gerrit Van Den Dool (2001), "Cyclically-adjusted budget balances: an alternative approach,” ECB Working Papers No 77.

Catão Luis and Bennett Sutton (2002), "Sovereign defaults: the role of volatility," IMF Working Paper No 02/149.

Crowe, Christopher and Ellen Meade (2008), “Central bank independence and transparency: evolution and effectiveness," IMF Working Paper No 08/119.

Darby, Julia and Jacques Mélitz (2008), "Social spending and automatic stabilizers in the OECD," Economic Policy 56, 715-56.

Debrun, Xavier, Jean Pisani-Ferry, and André Sapir (2008), "Should we forsake automatic stabilization?," European Economy-Economic papers No 316.

Debrun, Xavier, David Hauner and Manmohan Kumar (2009), "Independent fiscal agencies," Journal of Economic Surveys 23, 44-81.

Debrun, Xavier and Radhicka Kapoor (2010), "Fiscal policy and macroeconomic stability: automatic stabilizers work, always and everywhere," IMF Working Paper No 10/111.

Dolls, Mathias, Clemens Fuest, and Andreas Peichl (2009), “Automatic stabilizers and economic crisis," CESifo Working Paper No 2878. 
Eichengreen, Barry, Ricardo Hausmann, and Juergen von Hagen (1999), "Reforming budgetary institutions in Latin America: the case for a national fiscal council," Open Economies Review 10, 415-442.

Fatás, Antonio, and Mihov, Ilian (2001), “Government size and automatic stabilizers: international and intranational evidence," Journal of International Economics 55, 3-28.

Fatás, Antonio, and Mihov, Ilian (2003), "The case for restricting fiscal policy discretion," Quarterly Journal of Economics 118, 1419-47.

Fatás, Antonio, and Mihov, Ilian (2009), “The euro and fiscal policy,” NBER Working Paper No 14722.

Fedelino, Annalisa, Anna Ivanova and Mark Horton (2009), "Computing cyclically-adjusted balances and automatic stabilizers," IMF Technical Notes and Manuals No 09/05.

Furceri, Davide (2009), "Stabilization effects of social spending: empirical evidence from a panel of OECD Countries," North American Journal and Economics and Finance 21, 34-48.

Gavin Michael and Roberto Perotti (1997), "Fiscal policy in Latin America," NBER Macroeconomics Annual 12, 11-72

Galì, Jordi (1994), "Government size and macroeconomic stability," European Economic Review 38, 117-132.

Galì, Jordi, and Roberto Perotti (2003), "Fiscal policy and monetary integration in Europe," Economic Policy 18, 533-72.

Girouard, Nathalie and Christophe André (2005), "Measuring cyclicallyadjusted budget balances for OECD countries," OECD Economics Department Working Paper No 434.

Henisz, Witold (2006), "The Political Constraint Index Dataset," Wharton School of the University of Pennsylvania.

Horton, Mark, Manmohan Kumar, and Paolo Mauro (2009), "The state of public finances: a cross-country fiscal monitor," IMF Staff Position Note No 09/21.

International Monetary Fund (2007), "The changing dynamics of the global business cycle," Chapter 2 of the October World Economic Outlook, Washington, D.C.. 
Kumhof, Michael, and Douglas Laxton (2009), "Chile's structural surplus rule: a model-based evaluation," IMF Working Paper No 09/88.

Lee Young and Taeyoon Sung (2007), "Fiscal policy, business cycles and economic stabilization: evidence from industrialised and developing countries," Fiscal Studies 28, 437-62.

Martinez-Mongay, Carlos, and Khalid Sekkat (2005), "Progressive taxation, macroeconomic stabilization and efficiency in Europe," European Economy-Economic papers No 233.

Mohanty, M. S. and Fabrizio Zampolli (2009), "Government size and macroeconomic stability,” BIS Quarterly Review December, 55-68.

Perotti, Roberto (2005), "Estimating the effects of fiscal policy in OECD countries," Proceedings, Federal Reserve Bank of San Francisco.

Persson, Torsten and Guido Tabellini (2000), Political Economics, The MIT Press, Cambridge, MA.

Rodrik, Dani (1998), "Why do more open economies have bigger governments?" Journal of Political Economy 106, 997-1032.

Romer, Christina, and David Romer (2008), "The macroeconomic effects of tax changes: estimates based on a new measure of fiscal shocks," University of California, Berkeley, November (elsa.berkeley. edu/ cromer/draft1108.pdf).

Silgoner, Maria-Antoinette, Gerhard Reitschuler, and Jesus Crespo-Cuaresma (2003), "Assessing the smoothing impact of automatic stabilizers: evidence from Europe," in Gertrude Tumpel-Gugerell and Peter Mooslechner (eds.), Structural Challenges for Europe, Edward Elgar.

Spilimbergo, Antonio, Steven Symansky, Olivier Blanchard, and Carlo Cottarelli (2008), "Fiscal policy for the crisis," IMF Staff Position Note No 08/01.

Talvi, Ernesto and Carlos Vegh (2005), "Tax base variability and procyclical fiscal policy in developing countries," Journal of Development Economics 78, 156-90.

Tornell, Aaron and Philip Lane (1999), "The voracity effect," American Economic Review 89, 22-46.

van den Noord, Paul (2002), "Automatic stabilizers in the 1990s and beyond," in Marco Buti, Jürgen von Hagen and Carlos Martinez- 
Mongay (eds.), The Behavior of Fiscal Authorities - Stabilization, Growth and Institutions, Basingstoke: Palgrave.

van der Ploeg, Rick (2005), "Back to Keynes?," CESifo Economic Studies 51/4, 777-822.

Virén, Matti (2005), “Government size and output volatility: is there a relationship?" Bank of Finland Discussion Papers No 8.

Wyplosz, Charles (2006), "European monetary union: the dark sides of a major success," Economic Policy 21, 207-61.

\section{APPENDIX}

\section{Data Sources}

Data on government size (general government expenditure as a percentage of GDP), GDP per capita, openness to trade, public debt (percentage of GDP), private consumption, dependency ratio and urbanization rates are obtained from the IMF World Economic Outlook Database. Financial development, which is captured by the total stock of credit by deposit money banks to private sector as percentage of GDP, and indices of oil prices are obtained from the IMF International Financial Statistics. Data on political and electoral systems is from the Database of Political Institutions (Beck and others, 2001). The political constraint index is from the POLCON database (Henisz, 2006). The index of government stability is from the International Country Risk Guide database. The index of Central Bank Independence is from Crowe and Meade (2008).

\section{Automatic stabilizers, fiscal multipliers and $\widehat{\phi}_{1}$}

It is useful to illustrate the link between our estimates of the impact of automatic stabilizers and conventional measures of fiscal policy effectiveness. For simplicity, the starting point is a log-linear, backward-looking IS equation:

$$
y=\lambda y_{-1}+\gamma_{0} d-\gamma_{1}\left(i-\pi^{\varepsilon}\right)-\gamma_{2}\left(e+\pi-\pi^{*}\right)+\gamma_{3} y^{*}+\varepsilon,
$$

with $0<\lambda<1$ and $\gamma_{0}, \ldots, \gamma_{3}>0$, 
where the output gap ${ }^{21} y$ depends on the government budget deficit $d$, the real interest rate, the real exchange rate, external demand, and a random disturbance (all these with obvious notations). The decomposition between the cyclical and the cyclically-adjusted deficit $\left(d^{s}\right)$ can be written as: $d=d^{s}-\alpha y$, where $\alpha>0$ denotes the sensitivity of the budget deficit to the output gap. The cyclically-adjusted deficit itself reflects the cyclical policy and a residual: $d^{s}=-\beta y+\mu$, with $\beta>0$. Hence, $d=-(\alpha+\beta) y+\mu$. Substituting for the budget deficit, we can write the long-run relationship $\left(y=y_{-1}\right)$ as follows:

$$
\begin{gathered}
y=\frac{1}{\left(1+\gamma_{0}(\alpha+\beta)-\lambda\right)}\left[\gamma_{0} \mu-\gamma_{1}\left(i-\pi^{\theta}\right)-\gamma_{2}(e+\pi-\right. \\
+v_{0} v^{*}+\varepsilon \text { l. (A.2) }
\end{gathered}
$$

Clearly, greater automatic stabilizers, a more countercyclical discretionary fiscal policy and a greater fiscal multiplier all contribute to offset IS shocks:

$$
\begin{aligned}
& \frac{\partial y^{2}}{\partial \epsilon \partial \alpha}=\frac{\partial y^{2}}{\partial \epsilon \partial \beta}=\frac{-\gamma_{0}}{\left(1+\gamma_{0}(\alpha+\beta)-\lambda\right)^{2}}<0, \\
& \frac{\partial y^{2}}{\partial \epsilon \partial \gamma_{0}}=\frac{-(\alpha+\beta)}{\left(1+\gamma_{0}(\alpha+\beta)-\lambda\right)^{2}}<0 .
\end{aligned}
$$

To illustrate how these fiscal policy parameters relate to the estimated impact of automatic stabilizers on output volatility in the empirical model, let us write the variance of the output gap as: ${ }^{22}$

$$
\operatorname{Var}(y)=\left(\frac{1}{1+\gamma_{0}(\alpha+\beta)-\lambda}\right)^{2} \operatorname{Var}(\xi),
$$

with $\xi=\left[\gamma_{0} \mu-\gamma_{1}\left(i-\pi^{\varepsilon}\right)-\gamma_{2}\left(e+\pi-\pi^{*}\right)+\gamma_{3} y^{*}+\varepsilon\right]$

This implies:

$$
\frac{\partial S d(y)}{\partial \alpha}=\frac{-\gamma_{0}}{\left(1+\gamma_{0}(\alpha+\beta)-\lambda\right)^{2}} S d(\xi)<0 \text {, and }
$$




$$
\frac{\partial S d(y)^{2}}{\partial^{2} \alpha}=\frac{2 \gamma_{0}^{2}}{\left(1+\gamma_{0}(\alpha+\beta)-\lambda\right)^{3}} S d(\xi)>0 .
$$

Stronger automatic stabilizers thus reduce the standard deviation of the output gap, but at a decreasing rate because stabilizers themselves run against the potency of exogenous fiscal impulses. This second-round effect likely explains why using the logarithm of government size (instead of its level) generally yields better statistical results. The link between $\widehat{\phi}_{1}$ and the fiscal policy parameters can be written as:

$$
\phi_{1}=\frac{\partial S d(y)}{\partial \log (\alpha)}=\frac{\partial S d(y)}{\frac{1}{\alpha} \partial \alpha}=\frac{-\alpha \gamma_{0}}{\left(1+\gamma_{0}(\alpha+\beta)-\lambda\right)^{2}} S d(\xi)
$$

Using equation (A.3), we can determine a range of values for $\widehat{\phi}_{1}$ consistent with plausible calibration of the various parameters. As $S d(\xi)$ is not observable, we simply assume - in line with recent empirical estimates $^{23}$ - that fiscal policy can stabilize about one third of shocks to $\xi$. We thus set $S d(\xi)$ equal to 1.5 times our sample's measure of output variability. Assuming ${ }^{24}$ that $\lambda=0.6$, that $\gamma_{0}$ spans over $[0.1 ; 1.5]$ and that government size can be anywhere between 0.2 and 0.6 , the implied values for $\phi_{1}$ lies between -2.64 and -0.48 . We can also use equation (A.3) to calculate, for given government size, the range of values of fiscal policy multipliers implicit in our estimates of $\phi_{1}$. Taking the sample average of government size of 0.38 and assuming that discretionary fiscal policy is acyclical $(\beta=0$ ), the 95 percent confidence interval of $\phi_{1}$ (i.e. $\left.[-2.81 ;-1.22]\right)^{25}$ maps into "fiscal multipliers" $\left(\left(\gamma_{0}\right)\left(1+\gamma_{0}(\alpha+\beta)-\lambda\right)^{-1}\right)$ between 0.4 and 1.5 . Replicating this exercise for the 95 percent confidence interval of $\phi_{1}$ using the standard deviation of the output gap as the measure of volatility (i.e. [-2.29;0.92]), we obtain somewhat lower multipliers (between 0.4 and 1.0).

23. For recent evidence, see Dolls, Fuest and Peichl (2009).

24. The value for the persistence parameter was set on the basis of the average value obtained in straightforward OLS estimations of equation (A.1) for a variety of advanced countries in our sample.

25. This refers to the regression (3) in Table 2 of the main text. 